\title{
Hodnota vzdělání
}

\section{u začínajících akademických pracovníků z perspektivy vybraných aspektů sebepojetí}

\author{
Iva Koribská
}

\begin{abstract}
Abstrakt
Tento příspěvek se zabývá otázkou, jakou hodnotu má vzdělání pro začínající akademické pracovníky z perspektivy vybraných aspektů sebepojetí. Hlavním cílem bylo zjistit, jakou prioritu má vzdělání v hodnotové orientaci respondentů. Dále jsme analyzovali faktory, které ovlivňují hodnotu vzdělání respondentů z pohledu kognitivního, emočního a konativního aspektu sebepojetí. Za výzkumný nástroj jsme si zvolili polostukturovaný rozhovor a odpovědi respondentů jsme podrobili otevřenému, axiálnímu a selektivnímu kódování.
\end{abstract}

Klíčová slova: akademický pracovník, doktorské studium, hodnota, hodnotová orientace, sebepojetí (self-concept), vědomí vlastní účinnosti (self-efficacy), sebehodnocení (self-esteem), seberealizace. 


\title{
The value of education for novice academic staff from the perspective of selected aspects of self-concept
}

\begin{abstract}
This article explores the value of education for novice academic staff from the perspective of selected aspects of self-concept. The main objective was to find out what priority education has in the value orientation of respondents. Furthermore, the factors that influence the value of education of respondents' cognitive, emotional and conative aspects of self-concept were analysed. A semi-structured interview was chosen as a research tool and the respondents' responses have undergone open, axial and selective coding.
\end{abstract}

Keywords: novice academic staff, doctoral study, value, value orientation, self-concept, self-efficacy awareness (self-efficacy), self-esteem, self-realization.

DOI: $10.5507 /$ epd.2019.021

\section{Úvod}

V příspěvku se zabýváme analýzou vybraných aspektů sebepojetí začínajících akademickým pracovníků PdF UP ve vztahu k hodnotě vzdělávání a samotného vzdělání. Pro tyto účely vybíráme část našeho výzkumu studentů různých ročníků doktorského studijního programu Pedagogika a absolventů do tří let po ukončení studia, kteří působí na PdF UP. Předpokládáme, že je hodnota vzdělání u zmíněných respondentů v popředí, avšak zajímá nás její přesnější umístění v hodnotové orientaci. Ve výzkumu se zabýváme důvody, které respondenty vedly k nástupu a dokončení studia. Dále zkoumáme faktory, které hodnotu vzdělání u respondentů ovlivňují a zda během studia dochází k posunu v jejich hodnotové orientaci. V následujícím teoretickém ukotvení proto budeme definovat pojmy hodnota (value), hodnotová orientace (value orientation), sebepojetí (self-concept), seberealizace (self-realization).

\section{Terminologické ukotvení}

V české odborné literatuře se definicí hodnoty zabývá například Spousta (2000), který ji vnímá jako vše, co má pro nás nějakou cenu. Hudeček (1986, s. 48-49) poukazuje na hodnoty jako stimulanty chování a jednání, které fungují jako významný činitel v motivační sféře. Ze zahraničních autorů se pojmu hodnota věnuje Rogers (in Kosíková, 
2011), který zdůrazňuje hodnoty zakládající se na vlastním prožitku. Náš výzkum se opírá o jeho tvrzení, že hodnoty určují ústřední pozici osobnosti, jeho chování a jednání a jsou nedílnou součástí vztahového rámce osobnosti. Hodnotu vzdělání vztahujeme v našem výzkumu k následné kategorizaci hodnot podle Frankla (2016): tvưrčí hodnoty, ke kterým se člověk vztahuje při plnění úkolů, které mu ukládá např́klad rodina nebo povolání, zážitkové hodnoty, které se realizují v prožívání a přijímání světa a postojové hodnoty, které se projevují v tom, jak se člověk postaví k nezměnitelnému osudu.

Hodnotovou orientaci si pro potřeby našeho výzkumu definujeme jako hierarchicky uspořádaný soubor hodnot, které regulují a usměrňuji chování člověka (Göbelová, 2008). Zjištujujeme, zda hodnotová orientace respondentů odpovídá změně v hodnotové orientaci současné společnosti podle Plamínka (2014), který vyzdvihuje hodnotu vzdělání, jenž člověku umožní chápat dnešní svět v souvislostech, naučí jej samostatně přemýšlet a může přispět k orientaci na jiné hodnoty jako poznání, zdravé životní prostředí, klid a bezpečí.

Hodnoty a hodnotová orientace tvoří nedílnou součást osobnosti. Ve výzkumu vycházíme z psychologického pojetí osobnosti pětifaktorové teorie formulované McCraeem a Costou (in Pravdová, 2016), který zahrnuje bazální tendence, charakteristické adaptace, sebepojetí, objektivní biografie a vnější vlivy. Sebepojetí se vytváŕí v procesu socializace a Ize jej definovat jako představu sebe sama, na které se podílejí poznávací, smyslové a citové faktory (Lukášová, 2015). Podle Heluse (2011) tvoří sebepojetí tyto čtyři základní složky: sebepoznávání, sebehodnocení, sebecit a seberealizace. V našem výzkumu vycházíme ze sociálně kognitivního náhledu Blatného (2010), který vymezuje tři aspekty sebepojetí: kognitivní, emoční a konativní.

V rámci kognitivního aspektu sebepojetí je pro náš výzkum podstatná struktura sebepojetí, která se skládá z jednotlivých reprezentací Já. Při výzkumu hodnotové orientace respondentů se opíráme o sebediskrepanční teorii (self-discrepancy theory) E. Tory Higginse ( in Pravdová, 2014) a zaměřujeme se na tři typy reprezentace Já: Já ideální (ideal self), Já skutečné (actual self) a Já požadované (ought self). Ideální Já se vztahuje k našim představám, jací bychom měli být. Skutečné Já obsahuje atributy, o kterých je jedinec přesvědčen, že jimi disponuje. Požadované Já vychází z představy o tom, co se po nás žádá, tedy z úkolů, povinností a nároků, se kterými se identifikujeme (Pravdová, 2014 , s. 21). Podle Blatného (2010) emoční složka sebepojetí neboli sebehodnocení (self-esteem) vyjadřuje vztah k sobě a Ize ji vymezit prostřednictvím termínů sebeúcta, sebedůvěra, sebevědomí apod. Při zkoumání jednotlivých faktorů ovlivňujících hodnotu vzdělání respondentů je pro náš výzkum podstatné, že v dospělosti jsou pro vytváření hodnocení o sobě samém důležité interakce se spolupracovníky, osobami z referenčních skupin a významnými rodinnými př́slušníky. Konativní aspekt sebepojetí v sobě zahrnuje motivační a seberegulační funkce, které se vztahují k naší potřebě sebejistoty a potvrzení vlastní hodnoty. Můžeme sem zařadit např́iklad sebeprezentační strategie nebo jednání vyplývající ze snahy dosáhnout ideálního Já (Pravdová, 2014, s. 23). Sou- 
částí konativního já je také seberealizace, která je podle Maslowa (1970) na vrcholu hierarchie potřeb a charakterizuje ji jako lidskou touhu po sebenaplnění. Přesto je podle Machalové (2016) obecně seberealizace uspokojená v průměru jen na $10 \%$, protože osobní růst může přinést strach, hrůzu, pocit slabosti a nedostatečnosti, kdy dochází k popření našich nejlepších stránek - tvořivosti. V seberegulačních procesech sehrává důležitou roli i přesvědčení jedince o vlastních schopnostech zvládat životní výzvy a úkoly, které Bandura (in Pravdová, 2014) označuje jako vědomí vlastní účinnosti (selfefficacy), tedy zda jedinec věři ve své schopnosti dosáhnout vytyčeného cíle.

\section{Metodologie}

\subsection{Specifikace výzkumu a metod}

Výzkumné šetření bylo zaměřeno na kvalitativní design a jako nástroj jsme použili polostrukturovaný rozhovor. Respondenti byli vybráni metodou sněhové koule z řad studentů doktorského studijního programu Pedagogika a jeho absolventů pracujících na PdF UP do tří let od ukončení studia. Respondentů bylo celkem osm, z toho pět studentů a tři absolventi. Šest respondentů bylo národnosti české, jeden indonéské a jeden čínské. Výzkumné šetření probíhalo během měsíce října roku 2017.Z důvodu náročnosti a obsáhlosti témat byly rozhovory s respondenty rozděleny do několika časových etap.

V první ćásti rozhovoru jsme se zaměřili na demografické údaje respondentů a jejich rodinné zázemí. Otázky byly směřovány na hodnotovou orientaci rodiny, ve které respondenti vyrůstali, dosažené vzdělání rodičů a podporu, kterou poskytovali respondentům při vysokoškolském studiu. Doplňujícími otázkami jsme zjištovali, jakou důležitost měla hodnota vzdělání v rodině při výchově respondentů. $V$ druhé části rozhovoru jsme navázali otázkou, se kterými hodnotami své původní rodiny se respondent ztotožňuje i nyní a předává je nebo by je rád v budoucnu předal svým dětem. Zjištovali jsme současnou hodnotovou orientaci respondentů a zaměřili jsme se na hodnotu vzdělání, konkrétně na hodnotu samotného procesu vzdělávání a získání titulu v rámci jejich doktorského studijního programu. Tato část také zahrnovala otázky z oblasti očekávání, jeho naplnění a překážek, které doktorské studium respondentům přináší. Dále jsme se dotazovali, zda během studia došlo $k$ posunu v hodnotové orientaci respondentů a které faktory tuto změnu zapríčinily. Ve třetí části rozhovoru jsme se zabývali adaptací respondentů na akademické prostředí, vztahy mezi kolegy na pracovišti, vztahy k jejich studentům a hodnotám, které se jim respondenti ve výuce snaží předat. Rozhovor byl zakončen otázkou, jak vnímají respondenti současnou společnost a zda se ztotožňují $s$ jejími hodnotami. Kladené otázky a následná analýza jednotlivých kategorií měly za cíl sledovat to, jakým způsobem respondenti nahlíží na hodnotu vzdělání v rámci 
hodnotové orientace a zjistit, která reprezentace sebepojetí podle sebediskrepanční teorie E. Tory Higginse je doktorským studiem nejvíce ovlivněna.

\subsection{Způsob analýzy dat}

Data byla v rámci výzkumu zjištována pomocí polostrukturovaného rozhovoru, který byl nahráván, přepsán a následně kódován. Respondenti byli požádáni, aby své odpovědi formulovali volně a jejich odpovědi nebyly nijak formálně ani časově limitovány. Získaná data jsme zpracovali otevřeným, axiálním a selektivním kódováním. Při otevřeném kódování jsme rozčlenili data do následujícího kategoriálního systému:

1. Demografické údaje odkazující na věk a pohlaví respondenta.

2. Rodinný stav, děti.

3. Dosažené vzdělání rodičů.

4. Podpora rodiny při vzdělávání.

5. Hodnotová orientace rodičů či jiné osoby, která je respondentovi blízká.

6. Hodnotová orientace respondenta.

7. Hodnoty spojené s doktorským studiem a získáním titulu Ph.D.

8. Posun v hodnotové orientaci během absolvování doktorského studijního programu.

9. Očekávání respondenta v rámci doktorského studijního programu.

10. Překážky respondenta bránící jeho seberealizaci.

12. Vztahy v pracovním kolektivu.

13. Ztotožnění se s hodnotami současné společnosti.

Při axiálním kódování jsme zvolili za fenomén hodnotu vzdělání, ke které vztahujeme $v$ rámci kognitivního aspektu sebepojetí tři příčinné podmínky opírající se o tři typy jednotlivých reprezentací Já sebediskrepanční teorie E. Tory Higginse (1987). První prríčinnou podmínkou je „kdo jsem“, které zahrnuje atributy, o kterých jsou respondenti přesvědčeni, že jimi disponují. Druhou př́činnou podmínkou je „kým bych měl být", která je určována atributy pramenící z požadavků, úkolů a povinností, které jsou na respondenty kladeny. Třetí př́činnou podmínku jsme stanovili „kým chci být", kterou tvoří prání, touhy a představy respondentů o tom, jací by chtěli ideálně být. Výsledky výzkumu naznačují, že skrze fenomén hodnoty vzdělání dochází v sebepojetí respondentů k posílení přičinné podmínky "kým chci být" a zároveň ke zvýšení vědomí vlastní účinnosti. Pro větší názornost uvádíme následující graf. 
Obr. 1

Grafické znázornění hodnoty vzdělání ve vztahu k sebepojetí respondentů

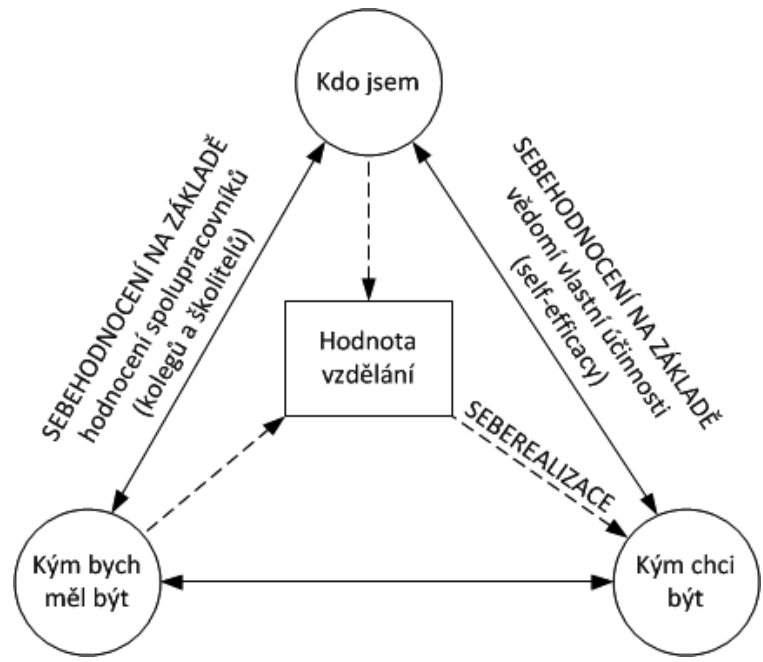

\subsection{Výsledky výzkumu}

Všichni respondenti uvedli, že mezi nejdůležitější hodnoty, ke kterým byli výchovou rodičů vedeni, byla hodnota soudržnosti s rodinnými příslušníky a morální hodnoty, zejména hodnoty slušného chování, které jim byli při výchově vštěpovány. Hodnota vzdělání byla ve všech původních rodinách zdůrazňována, lišily se však v odůvodnění důležitosti vzdělání. Rodiče, kteří dosáhli vzdělání zakončeného maturitou nebo výučním listem, chápali vzdělání především jako praktický prostředek k dosažení hmotného zabezpečení. Rodiče s vysokoškolským vzděláním spatřovali v hodnotě vzdělání navíc možnost rozvíjet své znalosti a kompetence. Většina rodičů respondenty finančně i psychicky podporovala během jejich bakalářského i magisterského studia. Tito respondenti z řady studentů doktorského studijního programu vnímají psychickou podporu rodičů při studiu i nadále, avšak finanční podporu rodičů uvádí jen respondenti do 27 let. Míru důležitosti hodnoty vzdělání, která je nepoměrná s respondenty původem z českého rodinného prostředí, uvádí respondent čínské národnosti. Ve své výpovědi zmiňuje autoritu k učiteli jako jednu z pěti nejvýznamnějších životních hodnot vedle autority k rodičům a lásky ke své vlasti. Zajímavé je také srovnání respondenta indonéské národnosti, který má hodnotu vzdělání zakotvenou ve své víre a tato hodnota tak získává duchovní charakter. 
Všichni respondenti uvádí, že stěžejní hodnoty, které si z původní rodiny přináší a zároveň chtějí předat vlastním dětem, jsou morální hodnoty a hodnota zdraví, rodiny a dobrých mezilidských vztahů. Hodnotu víry uvádí jako nejdůležitější respondent muslimského vyznání. U většiny respondentů nacházíme téměř plnou shodu v jejich hodnotové orientaci s hodnotovou orientací původní rodiny. Hodnotu samotného procesu vzdělávání v doktorském studijním programu spatřuje většina respondentů v seberealizaci, která vede k rozvoji osobnosti a získávání sebevědomí, nových zkušeností, překonávání překážek a pocitu z dobře vykonané práce. Právě úspěch při překonávání překážek a motivace formulovaná respondenty nejčastěji jako "dokázat si, že na to mám" je prríčinou posilování vědomí vlastní účinnosti respondentů. Hodnota získání doktorského titulu znamená pro většinu respondentů završení několikaletého úsilí, otevření možnosti pracovního uplatnění, zvýšení sociální prestiže a získání nových znalostí a kontaktů. Všichni absolventi uvádí, že se naplnila jejich očekávání ve vztahu k doktorskému studiu. Zklamání jim však přineslo velké množství administrativní práce, která s sebou pozice vysokoškolského učitele a výzkumníka přináší. Největší překážky bránící ve studiu spatřuje většina respondentů „sama v sobě“. Zejména respondenti ženského pohlaví uvádí jako největší překážku nedostatečné sebevědomí a trému. Výzkumem bylo dále zjištěno, že u starších ročníků doktorských studentů a absolventů dochází u respondentů mužského pohlaví ke značnému posunu v hodnotové orientaci směrem $\mathrm{k}$ rodině. Důvodem je predevším touha respondentů podílet se na výchově svých dětí a nepřicházet o pro ně význačné okamžiky v jejich progresu. Naopak u žen po mateřské dovolené posiluje hodnota seberealizace na úkor hodnoty rodiny, což $v$ důsledku způsobuje rozpor mezi tím, kým by tyto ženy chtěli být a co od nich druzí očekávají.

Přestože má většina respondentů obavy z formálního akademického prostředí, žádný z nich neprojevil nespokojenost s pracovním kolektivem, který respondenti vnímají jako podporující, pozitivní a starší kolegy a školitele jako ochotné naslouchat a pomoci. Vztahy na pracovišti jsou respondenty popisované jako kamarádské, neformální, inspirující a motivující. Pro většinu respondentů je kritické myšlení nejdůležitější hodnotou, kterou chtějí svým studentům předat. Po studentech vyžadují, aby porozuměli problémům, dovedli si udělat vlastní názor a ke studiu přistupovali poctivě. Celkově se respondenti neztotožňují s hodnotami současné společnosti, kterou vnímají jako př́liš materiálně zaměěenou, uspěchanou, orientovanou na výkon a peníze, nepodporující individualitu a vlastní názor, neaktivující zájem o současné problémy. Ve společnosti postrádají spiritualitu, morální hodnoty, skromnost a schopnost řešit problémy. 


\section{Diskuze a závěry}

Výzkumem bylo zjištěno, že skrze hodnotu vzdělání dochází u respondentů k posílení kognitivní složky sebepojetí „kým chci být", tedy našeho ideálního já. Překonávání překážek při doktorandském studiu zvyšuje u respondentů v rámci sebehodnocení z pohledu "kdo jsem“ vědomí vlastní účinnosti. Na základě pozitivního pracovního prostředí a pozitivní zpětné vazby školitelů dochází v sebehodnocení respondentů také k posílení „kým bych měl být", $v$ kontextu našeho výzkumu tedy k posílení profesní složky sebepojetí. Většina respondentů spatřuje nejdůležitější hodnotu samotného procesu vzdělávání v doktorském studijním programu v seberealizaci, která jim umožňuje stát se „kým chci být".

Změnu v hodnotové orientaci zaznamenáváme u respondentů, kteří prochází zásadními životními změnami, například se stanou rodiči nebo řeší závažné zdravotní komplikace. $Z$ genderového pohledu na hodnotu vzdělání se $v$ našem dalším výzkumu nabízí zkoumat faktory, které ovlivňují diskrepanci mezi „kým bych měl být" a „kým chci být" u studentek a absolventek doktorského programu po mateřské dovolené.

Rozdílnost ve vnímání hodnoty vzdělání mezi respondenty české a jiné národnosti nás při výzkumu navádí k vybrání většího počtu respondentů ze zahraničí, provést hlubší analýzu a srovnání.

Další výzkum bychom chtěli zaměřit na aspekt profesního sebepojetí začínajících akademických pracovníků. Problematikou profesního sebepojetí učitelů se zabývá např. Pravdová (2016) nebo Lukášová (2015), jejichž výzkumem chceme podložit naše budoucí výzkumné šetření.

\section{Literatura}

Blatný, M. (2010). Sebepojetíz pohledu sociálně-kognitivní psychologie. In M. Blatný et al., Psychologie osobnosti. Hlavní témata, současné př́stupy. Praha: Grada.

Frankl, V., E. (2016). A přesto říct životu ano. Kostelní Vydří: Karmelitánské nakladatelství.

Göbelová, T. (2008). Hodnotová výchova v pedagogické praxi. Ostrava: Ostravská univerzita.

Horák, J. (1997). Kapitoly z teorie výchovy I. a Il. Problematika hodnot a hodnotové orientace I. díl. Liberec: TU v Liberci.

Helus, Z. (2011) Úvod do psychologie. Praha: Grada Publishing.

Hudeček, J. (1986) Hodnotové orientace v motivační sfére osobnosti. Praha: Academia.

Jandourek, J. (2007). Sociologický slovník. Praha: Portál.

Kosíková, V. (2011). Psychologie ve vzdělávání a její psychodidaktické aspekty. Praha: Grada Publishing, a. s.

Lukášová, H. (2015) Učitelské pojetí a jeho zkoumání. Zlín: Univerzita Tomáše Bati.

Machalová M. (2016) Vyspelost' človeka z pohladu humanistického psychológa Abrahama Maslowa. Prohuman [online]. [cit. 2017-12-12]. Dostupné z: http://www.prohuman.sk/psychologia/ vyspelost-cloveka-z-pohladu-humanistickeho-psychologa-abrahama-maslowa.

Maslow, A. (1970). Motivation and personality. New York: Harper \& Row. 
Plamínek, J. (2014). Vzdělávání dospělých. Praha: Grada Publishing, a. s.

Pravdová, B. (2014). Já jako učitel: profesní sebepojetí studenta učitelství. Brno: Masarykova univerzita. Průcha, J. (2014). Andragogický výzkum. Praha: Grada Publishing, a. s.

Spousta, V. (2000). Vádemékum autora odborné a vědecké práce (se zaměřením na práce pedagogické). Brno: Masarykova univerzita.

Švařiček, R., Šed’ová, K. \& kol. (2007). Kvalitativní výzkum v pedagogických vědách. Praha: Portál. Frankl, V. E. (2016). A presto říct životu ano. Kostelní Vydří: Karmelitánské nakladatelství.

\section{Kontakt:}

Mgr. Iva Koribská

Ústav pedagogiky a sociálních studií

Pedagogická fakulta Univerzity Palackého v Olomouci

Žižkovo náměstí 5, 77140 Olomouc

E-mail: iva.koribska@upol.cz

Mgr. Iva Koribská je doktorandkou studijního programu Vzdělávání na Institutu sociálních věd a vzdělávání Univerzity Palackého v Olomouci, kde také působí jako asistentka. Specializuje se na vzdělávání dospělých a faktory budování profesního sebepojetí akademických pracovníků. 